\title{
Application of Grounded Theory in Career Research Reviewed
}

\author{
Adelé Janse van Rensburg \\ Wilfred I. Ukpere \\ Department of Industrial Psychology and People Management, Faculty of Management, \\ University of Johannesburg, Johannesburg, South Africa \\ Email: wiukpere@uj.ac.za
}

\section{Doi:10.5901/mjss.2014.v5n4p543}

\begin{abstract}
Most research studies pose some element of concern, discrepancies and controversy. Grounded theory (GT) research is not an exception. This paper provides an overview of how GT was applied in a PhD study about career transition phenomenon. It should be noted that it is not the intent of this paper to provide a detailed account of the completed study, but rather to provide a practical example of the process followed, which first-time GT researchers might find useful. Therefore, firstly, this paper provides an overview of GT in general, including two of the most controversial topics which are the use of literature and the application of qualitative data analysis (QDA) programs. Secondly, the researcher's school of thought and her first-hand account of how grounded theory was applied, is explained.
\end{abstract}

Keywords: Grounded theory; Career; Transition; Phenomenon

\section{Introduction and Background to Grounded Theory}

A historical overview of grounded theory shows that the concept was developed in 1967 by Barney Glaser and Anselm Strauss in their book The Discovery of Grounded Theory. The specific term grounded theory, was chosen to indicate that theory is generated from or grounded in the data (Pidgeon \& Henwood, 1997). The development of GT was influenced mainly by two schools of thought - the Chicago School of Symbolic Inter-Actionism and the Columbia School of Multivariate Analysis (LaRossa, 2005). This theory emerged mainly because the two founders contested the view of the positivist who believed that external reality can be studied in a detached and objective manner as it exists independently of human influence (Locke, 2001; Terre Blanche \& Durrheim, 1999; Suddaby, 2006). Instead, the two founders believed that "social reality is not a given. It is built up over time through shared history, experience and communication, so that what is taken for 'reality', is what is shared and taken for granted as to the way the world is to be perceived and understood" (Locke, 2001:9). In other words, grounded theorists are not concerned with testing prior theories, but rather with how participants view reality themselves (LaRossa, 2005; Locke, 2001).

\section{The Great Contestation in Grounded Theory}

More than ten years after their original GT publication, the two original authors diverged paths as a result of disagreements about "the nature of the method and how it ought to be practiced" (Willig, 2001, p. 42). Ironically, the use of GT began to grow only after this divergence (Bryant \& Charmaz, 2007). For the period 1991 to 1998, the GT method was $64 \%$ more utilised than any other qualitative or quantitative methods (Bryant \& Charmaz, 2007). This trend continued and resulted in GT being the most widely used within the qualitative approach (Bryant \& Charmaz, 2007; Morse, Stern, Corbin, Bowers, Charmaz, \& Clarke, 2009). For example, "GT has spread to wider practitioner fields such as nursing, education, psychology, accounting, business management, public health, social work and LIS over the last 40 years" (Tan, 2010:94). Following the diversion of the two authors, two schools of thought, namely the Glaserian \& the Straussarian emerged (Chioviti, 2003). The Glaserian School represented an orderly process for conceptualisation (Glaser, 2002) whilst the Straussarian School stressed complex coding techniques (Goulding, 1999). However, the basic principles of GT remained and are applicable to both schools. The specific school of GT followed for a study depends on the "nature of the relationship between the researcher and participant" (Mills, Bonner, \& Francis, 2006:2). Although the ontological and epistemological stance of the researcher influences the point of departure, a set of common criteria such 
as coding, theoretical sampling, and constant comparative methods directs all GT studies (Mills, Bonner, \& Francis, 2006).

The diversion of the two founders of GT lead to various adaptations and in some cases even abuse. Bryant and Charmaz (2007, p. 11) explain the various adaptations as a "family of methods". The reference to family indicates that although each version is unique in itself, it also belongs to a family with certain main characteristics:

- Locke 2001) explains that it is extremely important that the researcher enters the study with as little pre-set assumptions about the phenomenon that is studied as possible. Rather, the researcher should derive a theory through thorough engagement, participation and interaction with the phenomenon that is studied.

- Unlike other qualitative research, GT requires that the researcher identifies new concepts from the data instead of using pre-defined concepts, which are developed by someone else (Glaser, 2002). However, this does not mean that literature should be ignored completely. It merely suggests that the researcher should be aware of the existing literature and the influence that it might have on their observations (Suddaby, 2006).

As the use of literature in GT studies is a very controversial topic, the next section provides more insight.

\section{The Use of Literature in Grounded Theory}

To do or not to do. This seems to be a major factor in GT studies as many researchers believe in including literature prior to and during data analysis whilst some researchers believe that literature should be excluded until all analysis has been done. Mills, Bonner and Francis (2006:4) labelled these two contesting groups as "traditional" and "evolved" grounded theorists, where traditional GT's believe that literature should only be included at the end of the research project, while evolved GT's believe that literature should be included right from the start. Table 1 provides quotations for and against the use of literature in GT between evolved and traditional GT's views.

Table 1: The Use of Literature in GT

\begin{tabular}{|l|l|}
\hline \multicolumn{1}{|c|}{ Evolved Grounded Theorists } & \multicolumn{1}{|c|}{ Traditional Grounded Theorists } \\
\hline - "use any material bearing in the area" (Glaser \& Strauss, 1967:169) & $\begin{array}{l}\text { "there is a need not to review any of the literature } \\
\text { in the substantive under study" (Glaser, 1992:31) }\end{array}$ \\
- Including literature leads to "accumulated knowledge" (Dey, 1993: 66) & $\begin{array}{l}\text { "there is no need to review any of the literature [in } \\
\text { order].... not to contaminate, or inhibit, the } \\
\text { - "A review of the relevant literature established current thinking" (Allan, }\end{array}$ \\
$\begin{array}{ll}\text { 2003:7) } & \text { A literature review prior to and during the research process "provide a a } \\
\text { foundation, background, and context for new research" (Bowen, 2005:210) } & \text { 2008:36) }\end{array}$ \\
\hline
\end{tabular}

Source: Authors' compilation

In addition to the arguments presented in Table 1, Suddaby (2006) identified that one of the misapplications of GT seem to be researchers not including literature as they claim that this enables them to build their own theory without any outside influence. Pidgeon and Henwood (1997:255) also argue that the exclusion of literature is not possible as "the researcher needs at least some theoretical resources to begin the process of interpretation and representation". Therefore, for this study, an initial literature review ensured that the researcher did not present supposedly new findings which have already been developed by other researchers (Bryant \& Charmaz, 2007), which relates to the evolved grounded theorist category. In addition, LaRosse (2005:850) contended that an initial literature review "significantly influences coding, even if the researcher is unaware that it does". Bryant and Charmaz (2007:20) sum it up:

In order to participate in the current theoretical conversation, I need to understand it. I must recognise that what may seem like a totally new idea to me - an innovative breakthrough in my research - may simply be a reflection of my ignorance of the present conversation. A literature review provides me with the current parameters of the conversation that I hope to enter... it does not, however, define my research.

Considering this viewpoint, a continuous referral to literature is proposed as this enables the "discovery or emergence of theory" due to the interaction between the literature, data collected and the researcher's own interpretations (Pidgeon \& Henwood, 1997:255).

To complicate the literature debate even further is the fact that the evolved grounded theorists cannot even agree on when to conduct a literature review. Table 2 provides an overview of some of the existing opinions ranging from views 
between the creation of the original GT to the more recent and contemporary views on the place of literature in GT.

Table 2: Literature Review in GT

\begin{tabular}{|c|c|}
\hline Arguments AGAINST a Literature Review & Arguments FOR a Literature Review \\
\hline $\begin{array}{l}\text { - "The first step in gaining theoretical sensitivity is to } \\
\text { enter the research setting with as few } \\
\text { predetermined ideas as possible" (Glaser, } \\
\text { 1978:3). } \\
\text { - Some researchers believe that literature should be } \\
\text { avoided at all cost as to not "contaminate their } \\
\text { coding" (LaRossa, 2005:850). } \\
\text { - "There is a need not to review any of the literature } \\
\text { in the substantive area under study" (Glaser, } \\
\text { 1992:31). } \\
\text { "Grounded theory must be free from the idea of } \\
\text { working on someone else's product" (Reetley, } \\
\text { 2008:37). }\end{array}$ & $\begin{array}{l}\text { - "Acknowledge the value of reviewing prior research" (LaRossa, 2005:250). } \\
\text { - Inclusion of literature adds another voice to the one of the researcher (Mills, } \\
\text { - Ponner, \& Francis, 2006). } \\
\text { - } \text { similarities, differences and reasons thereof to one's study. } \\
\text { - "After data have been .... analysed, then the researcher may begin to review } \\
\text { the literature in the substantive field and relate the literature to her/his own } \\
\text { work" (Reetley, 2008:37). } \\
\text { - "A common misperception is that grounded theory requires a researcher to } \\
\text { enter the field without any knowledge of prior research" (Suddaby, 2006:634). } \\
\text { - "Careful analysis of relevant extant literatures after developing one's grounded } \\
\text { theory can provide cues for raising its theoretical level" (Bryant \& Charmaz, } \\
\text { 2007:20). }\end{array}$ \\
\hline
\end{tabular}

\section{Source: Authors' Compilation}

Following the above divergent views, LaRossa (2005:850) adequately concluded that "how prior work should be used is up to the individual researcher". This viewpoint is confirmed by Bowen (2005, p. 210) who stated that:

The first lesson I learned was to read extensively and then read some more... After all, one needs to know what research exists and how others have treated a particular topic so one can determine what additional research is needed. Prior studies provide a foundation, background, and context for new research; it establishes a bridge between the (proposed) research project and the extant knowledge base.

Another controversial topic in the application of GT is the use of qualitative data analysis programs. The next section provides more insight.

\section{The Use of Qualitative Data Analysis (QDA) Programs in GT}

One of the main problems experienced by qualitative researchers is that of working through a vast amount of raw data (Pidgeon \& Henwood, 1997). A possible solution to this is the use of qualitative data analysis (QDA) ${ }^{1}$ programs (Bowen, 2005) or computer assisted qualitative data analysis software (CAQDAS) (Rettie, Robinson, Radke, \& Ye, 2008). However, much controversy exists on the use of these software programs as these programs are not universally accepted (Atherton \& Elsmore, 2007). Some of the concerns raised in literature indicated that most of the negative attitudes might be as a result of misperceptions about how the software is generally applied as well as a concern that the data analysis part will be done by the program itself. This resistance might be due to the fact that research indicates minimal application of QDA programs even though researchers are aware of it (Rettie, Robinson, Radke, \& Ye, 2008).

In order to test the aforementioned concerns, the researchers utilised a QDA program called Atlas.ti to determine the validity of the concerns through first-hand experience. As a test, a brief literature review on the topic of QDA programs was done to examine the pros and cons, overall usage, and general acceptance of QDA programs to researchers, whilst using the Atlas.ti program. The reason for choosing Atlast.ti for this study was because this program (among others) was specifically designed for the use of GT (LaRossa, 2005). In addition, it is also a standard program used and supported by the university. Therefore, if any additional assistance or support for the program was required, it was relatively easy to come by.

\subsection{High Level Overview of QDA Programs}

This review revealed two opposing views on the use of QDA programs. Some views can be generally attributed to ignorance on the use of QDA programs whilst others have more substantial concerns. Both views are briefly discussed.

${ }^{1} \mathrm{QDA}$ and CAQDAS can be used interchangeably, therefore the QDA abbreviation will be used for this study 
Table 2 highlights the main concerns identified and also provides counter arguments to that concern.

Table 2: Two Opposing Views

\begin{tabular}{|c|c|}
\hline Concern & Counter-argument \\
\hline $\begin{array}{l}\text { "Analysts may confuse coding with } \\
\text { analysis, and neglect interpretation" } \\
\text { (Rettie, Robinson, Radke, \& Ye, 2008, p. } \\
\text { 77) }\end{array}$ & $\begin{array}{l}\text { - QDA programs do not provide a method for coding, nor does it prevent substantial } \\
\text { intuitive analysis (Rettie, Robinson, Radke, \& Ye, 2008). } \\
\text { - Allows more time to the researcher for analytic and interpretive work as the } \\
\text { program takes care of the mechanical aspects of the process (Rettie, Robinson, } \\
\text { Radke, \& Ye, 2008). } \\
\text { - Although the program allows searches within the data to identify patterns, } \\
\text { interpretation of the data can only be done by the researcher as the researcher still } \\
\text { needs to specify what patterns to look for (Guidry, 2002). } \\
\text { "Software assists the management and retrieval of data, but does not replace the } \\
\text { intuitive, interpretive aspects of analysis" (Rettie, Robinson, Radke, \& Ye, 2008, p. } \\
\text { 85) } \\
\text { - A software program "does not perform the analysis for the researcher, ... it is not } \\
\text { an artificial intelligence program that sifts through data to discover themes" } \\
\text { (Guidry, 2002, p. 101). }\end{array}$ \\
\hline $\begin{array}{l}\text { Use pre-defined analytical techniques, } \\
\text { including pre-defined codes (Atherton \& } \\
\text { Elsmore, 2007) }\end{array}$ & $\begin{array}{l}\text { - Depending on the program used, codes can either be pre-determined or developed } \\
\text { as the data are analysed (Denzin \& Lincoln, 2000) } \\
\text { - QDA programs are "neutral in intent and output" (Atherton \& Elsmore, 2007, p. 69) } \\
\text { as meaning and interpretation are provided by the researcher through the provision } \\
\text { of codes. }\end{array}$ \\
\hline $\begin{array}{l}\text { "Creation of too many codes and } \\
\text { consequent loss of understanding of the } \\
\text { overall picture" (Rettie, Robinson, Radke, } \\
\& Y e, 2008 \text { ) }\end{array}$ & $\begin{array}{l}\text { - An overview of the overall picture can be easily obtained as software programs } \\
\text { provide mechanisms to link information and find patterns (Guidry, 2002) }\end{array}$ \\
\hline
\end{tabular}

Source: Authors' Compilation

Table 2 indicates that when a software program is used, the analysis part (including but not limited to coding, judging, opinions, ideas and interpretation) can only be done by the researcher (Pandit, 1996). For this study, the QDA program mainly assisted with data management in the form of storage, ordering and easy retrieval (Atherton \& Elsmore, 2007; Rettie, Robinson, Radke, \& Ye, 2008). In conclusion, Atherton and Elsmore (2007, p. 73) summed up the use of QDA programs as "the point about the wider context is that most of us would recognise that all research methods are flawed, in one way or another. As such, the argument is not what are the weaknesses of the software packages, but what are their limitations in comparison with the limitations of other approaches?"

\subsection{The Researcher's Experience of Atlas.ti}

It was found that the process of searching for relevant literature, importing of documents and coding of the information were relatively easy to follow and execute as the program instructions are similar to any windows program. It was easy to extract a list of all the codes and related quotations to assist with the argument for and against the use of QDA programs as described above.

It was not the purpose of this brief literature review on QDA programs to generate a theory, but rather to determine if theory can be generated using the Atlas.ti program. This part was difficult and not as user friendly as the beginning steps. It was found that a novice user definitely needs some assistance to instruct the program. The positive outcome of this was that it proofed that the data analysis part is definitely done by the researcher and not by the program. In addition, the almost sequential steps of open, axial and selective coding seems to be merged together into one step.

\section{Application of GT in Career Research}

Following the introduction and general overview of GT, this section provides insight into how the principles of GT were applied for the career transition study. As explained earlier, many misconceptions and subsequent misapplications of GT 
exist (Suddaby, 2006), it is therefore important to explain how GT was applied in the career study as well as to specify the locale of the researchers.

\subsection{The Researchers' GT School of Thought}

It is important to note that GT will and can be acknowledged if the basic principles are applied. Similar to LaRosse (2005), the researchers believe that Glaser and Strauss (1967:8) encouraged other researchers to modify the details of the procedures according to their needs when they stated that "our principal aim is to stimulate other theorists to codify and publish their own methods for generating theory". For the study, the techniques of Corbin and Strauss (the Strausarian School of Thought) were applied, as it provided a systematic coding technique, which was relatively easy to follow and replicate.

\subsection{The Process Followed}

Figure 1 below provides a schematic overview of the research design and methodology that was followed for the study. It clearly indicates how the various sub-sections of the design fit as a whole, working towards a common goal of building a theory. However, the placement of GT in Figure 1 might be misleading as it might be understood as less important as it was the last section to be looked at before the methodology section. The truth is actually that everything from the research question to the methodology and lastly to the building of a theory was built on GT principles.

Figure 1: Overview of Research Design and Methodology

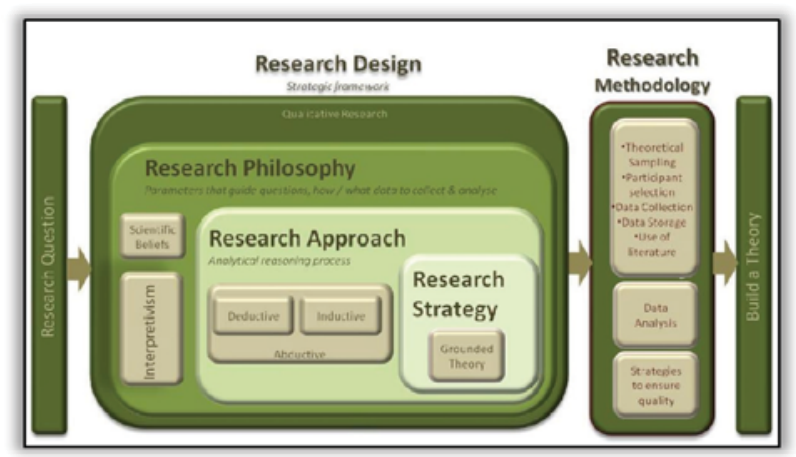

Source: Authors' Fieldwork

\subsection{Building a GT Framework}

This study commenced with a research problem which stated that: "no integrated, end-to-end view on the career transition phenomenon, which describes the how; what; when and why of inter-profession career transition from the viewpoint of the transitioning individual, existed previously". The research design facilitated the process to answer the research question through the provisioning of a structure in which the research was conducted. Within the qualitative research design, parameters that guided the research problems, as well as what and how data was collected and analysed, were set (Crosson, 2005). These parameters are called the research philosophy or paradigm, and provides a "view about the way knowledge is developed and judged as being acceptable" (Saunders, Lewis, \& Thornhill, 2003:83). Within the maze of research philosophies, Watson (2005) emphasizes that the first step should be based on the researcher's own beliefs because "the choices for our beliefs are constrained by the knowledge or cultural context in which we live" (Scheurich, 1997:34). Therefore, in summary, the key scientific beliefs of the researcher as an interpretivist can be explained as being a researcher who "relies on first-hand accounts, tries to describe what it sees in rich detail and presents its 'findings' in engaging and sometimes evocative language" (Terre Blanche \& Durrheim, 1999:124).

Furthermore, Terre Blanche and Durrheim (1999:123) explained interpretisvism as "methods that try to describe and interpret people's feelings and experiences in human terms rather than through quantification and measurement". Therefore, in order for the researcher to make sense of the career transitions of the participants, there was a need to 
understand their subjective meanings (what motivated them).

Following the research philosophy, the research approach explains the analytical reasoning process that the researcher employed (Thorne, 2000). For the purpose of this study, a combination of an inductive and deductive approach was applied, as the objective of the study was to build theory from data (inductive), however, deductions were also made from the data via questions, sampling, categories, and so on (Saunders, Lewis, \& Thornhill, 2003; Strauss, 1987). This process, which combines induction and deduction is called abduction (Bryant \& Charmaz, 2007) which is illustrated in Figure 2. "Abduction inference entails considering all possible theoretical explanations for the data, forming hypothesis for each possible explanation, checking them empirically by examining data, and pursuing the most plausible explanation" (Charmaz, 2006, p. 188).

Figure 2: Illustrative view of Inductive and Deductive Reasoning

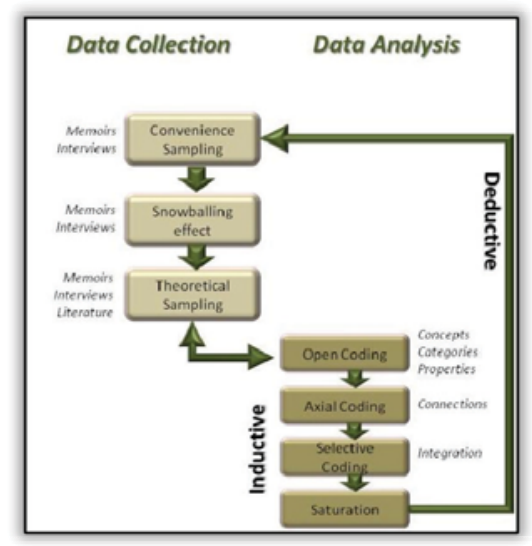

Source: Authors' Fieldwork

As evident from the above, the whole research design supported the concept and principles of GT. The research methodology followed is discussed in the next section.

\subsection{Applying a GT Framework}

The first point of locating the data was "by going to places and talking to people who are most likely to be able to provide some insight into the problem" (Goulding, 2002, p. 107). Therefore, initially, people known to the researchers, and who have made a career transition, were targeted. The first sample was professionals within the engineering profession in South Africa. Later on, these interviewees identified other possible participants. This process is called "snowballing", as the rolling snowball grows larger as it rolls down the mountain side (Terre Blanche \& Durrheim, 1999, p. 383). Since it was impossible to gather data from all individuals who may have transitioned in their career, a selection from those individuals was made. This process is called sampling. Lunsford and Lunsford (1995, p. 105) define sampling as "a subset of subjects representative of a given population". In other words, sampling is where the researcher makes decisions about whom or what will provide the most relevant data in order to answer the research question (Terre Blanche \& Durrheim, 1999).

Figure 3 below depicts the sampling process diagrammatically, as briefly explained below. Through convenience sampling, the first step was identification and selection of the most obvious cases (individuals who have transitioned in their career). The second technique is called purposive sampling. In practical terms, the researcher selected new cases on the basis of the data that was already analysed in order to enhance the information (Locke, 2001; Terre Blanche \& Durrheim, 1999). This was done by choosing between three options (Yin, 1989, p.53-54 as cited in Pandit, 1996):

- choose a case to fill theoretical categories, to extend the emerging theory

- choose a case to replicate previous case(s) to test the emerging theory

- choose a case that is polar opposite to extend the emerging theory

Lastly, theoretical sampling was applied. Goulding (2002:66) defines theoretical sampling as "purposeful selection of a sample according to the developing categories and emerging theory". Therefore, sampling in GT moves from 
sampling for specific individuals (convenience) to sampling in terms of concepts and categories (purposeful and theoretical) (Corbin \& Strauss, 1990).

Figure 3: Diagrammatic depiction of sampling process

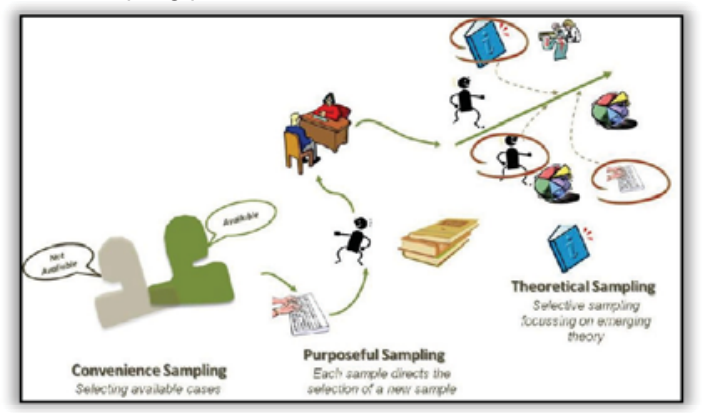

Source: Authors' Fieldwork

With this study, analysis commenced with data gathering and was continually done throughout the process (Corbin \& Strauss, 2008). Data was gathered from the first case, which was chosen for the generation of a rich data set, to the follow-up cases, which were selected to provide more focussed data (Locke, 2001), continuously until a point of theoretical saturation was reached. Theoretical saturation implies that data is collected until "no new evidence appears" (Suddaby, 2006:636), or until the researcher delivered enough information to describe the phenomenon under study. Following this, data was collected by using three methods which included participant memoirs, individual interviews and existing literature.

Conventional sampling techniques require that the researcher first collects all the data and then commences with the analysis. However, with interpretive research and specifically with GT, there is no clear linear process of first data collection and then data analysis. Rather, it is an iterative process where one flows naturally into the other on a continuous basis, but where the analysis part becomes more prominent towards the end of the research (Goulding, 2002; Locke, 2001; Pandit, 1996; Terre Blanche \& Durrheim, 1999; Bryant \& Charmaz, 2007). This iterative process ensures that the data is more focussed, and that the analysis is more theoretical (Bryant \& Charmaz, 2007). The aim of the data analysis process was to find answers for the research question (Terre Blanche \& Durrheim, 1999). Data analysis was done through coding. Strauss (1987:55) sums up the coding process as follows:

(1) both follows upon and leads to generative questions; (2) fractures the data, thus freeing the researcher from description and forcing interpretation to higher levels of abstraction; (3) is the pivotal operation for moving toward the discovery of a core category or categories; and so (4) moves toward ultimate integration of the entire analysis; as well as (5) yields the desired conceptual density.

The initial data analysis phase commenced with a process called open coding. Open coding is defined by Strauss (1987:28) as "unrestricted coding of the data". The open coding process began with identifying concepts and labelling them. Concepts were identified through scrutinizing the raw data in order to fully understand what the participants meant. From this understanding, the researcher derived at broad statements - a concept - which described that understanding. Concepts are defined as "words that stand for ideas contained in the data. Through a more detailed analysis the concepts were grouped into categories where both similar and contrasting instances were labelled. Categories are a grouping of instances which "share central features or characteristics with one another" (Willig, 2001:33).

In addition, a process called "constant comparative analysis" refers to the researcher being "constantly alert to the similarities and differences which exist between instances, cases and concepts" (Pidgeon \& Henwood, 1997, p. 261). This process of continually comparing one piece of the data with all the other previously collected data in order to identify similarities or differences resulted in categories and emerging sub-categories (Chiovitti \& Piran, 2003; Locke, 2001; Pandit, 1996; Strauss, 1987; Willig, 2008). Categorization is the "grouping of putatively similar but not identical concepts under a more abstract heading" (LaRossa, 2005:842).

Whilst concepts describe an idea within the raw data, categories require interpretation of the raw data into a higher level (Willig, 2008) through the making of deductions in the form of "theoretical questions, hypothesis suggested, theoretical sampling, possible categories, and so on" (Strauss, 1987:13). It should be noted that not all concepts 
necessarily became part of a category; neither did all concept groupings achieved the status of a category (Corbin \& Strauss, 1990). Only those concept groupings which explained the conditions, actions / inter-action and consequences of a phenomenon did constitute a category (Corbin \& Strauss, 1990). The last step in open coding was propositions which indicated where the researcher identified relationships between the concepts and categories (Pandit, 1996). In other words, the propositions "state how variables are related" (LaRossa, 2005:838). The end state of the open coding process resulted in eight broad career transition related categories.

After the initial breaking down of data into concepts and categories, the next phase, called axial coding, involved placing the data back together in new logical ways (Pandit, 1996). The main purpose of axial coding was to gyrate around the centre (axis) of a category (Charmaz, 2006; Saunders, Lewis, \& Thornhill, 2003), which resulted in the identification of relationships between categories and sub-categories through a combination of inductive and deductive reasoning. Questions that were asked during the process of axial coding included "when, where, why, how, and with what consequences" (Charmaz, 2006:60). Axial coding led to the final five career transition categories. Selective coding was the last phase of coding. It "pertains to coding systematically and concertedly for the core category", as this core code became the "guide to further theoretical sampling and data collection" (Saunders, Lewis, \& Thornhill, 2003:33). A core category is a combination of all information in order to provide an explanation of the behaviour under study. Unlike open coding, where as much codes as possible are required, selective coding means limiting the coding to only those that relate to the core category (Giske \& Arthinian, 2007). According to Glaser (1978), as cited by Goulding (2002:88), "a core category is a main theme which sums up a pattern of behaviour". After the testing and confirmation of the core category, the following phrase was developed to describe the core category: "Personal preferences as a set of interrelated beliefs and passions not only influence but also lead the career transition of professionals from beginning to end".

It is important to note that the choosing of a core category was the choice of the researcher as another researcher might have chosen a different path. Corbin and Strauss (2008:266) sum it up as: "The core concept and other concepts come from the data but 'theory' doesn't just build itself; in the end, it is a construction build by the analyst from data provided by participants". This core category was the basis from which the whole career transition story was told.

\section{Strategies to Ensure Quality of Data}

Strategies to ensure the quality of the outcome of any study is important as readers and examiners of the study inevitably ask the question: how did you know? Saunders, Lewis and Thornhill (2003:100) conclude that "in the literal sense of the question, you cannot know. All you can do is to reduce the possibility of getting the answer wrong". Therefore, to reduce the possibility of being wrong, a variety of strategies have been applied for this study. However, as stated previously, controversy exists within the qualitative research domain, and thus also exists in opinions about how to determine the trustworthiness of the study. Two opposing views exists, namely one which uses traditional rigour strategies and a parallel view, which applies the newer trustworthiness criterion that was originally introduced by Guba and Lincoln (1981). Figure 5 portrays the parallel between the conventional criterion for rigour versus the redefined trustworthiness criterion for qualitative studies and, in particular, for GT (Bowen, 2005).

Figure 5: Strategies to ensure quality of data

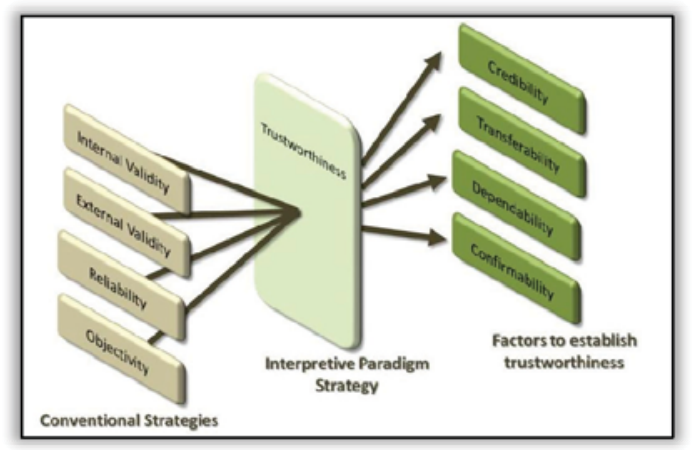

Source: Authors' Fieldwork 
It is important to note that regardless of the view of the researcher in terms of using the traditional rigour or more conventional trustworthiness, the criteria and standards that are used should be applied consistently throughout the study, and not only at the end to evaluate or judge the quality (Morse, Barrett, Mayan, Olson, \& Spiers, 2002). Each of the strategies and their relevant quality methods is discussed below.

\subsection{Internal validity and credibility}

"It involves the approval of research findings by either interviewees or peers; as realities may be interpreted in multiple ways" (Riege, 2003:81). Crescentini and Mainardi (2006) conclude that the major difference between internal validity and credibility is owing to the smaller sample size of qualitative studies, since it is claimed that smaller sample sizes cannot be validated. However, they also argue that the depth and richness of qualitative research counteract the smaller sample size (Crescentini \& Mainardi, 2009). Some of the methods applied were:

- A process where three sources of data were used, including memoirs; interviews and literature to confirm the findings (Bowen, 2005; Terre Blanche \& Durrheim, 1999).

- Member validation - This entailed a process where participants were contacted and requested to verify the accuracy of the initial findings (Bowen, 2005). In doing member checking, it is crucially important that the participants understand that this study "is not their voice: it is a generated abstraction from their doings and their meanings that are taken as data for the conceptual generation" (Glaser, 2002:5).

- Peer debriefing - "The peer reviewer should evaluate all areas of the research to include decision-making, methodology, legal and ethical issues, and other matters pertaining to the research" (Lewis, 2009:13). This implies that colleagues should review the analysis process, which should result in interpretations on a regular basis (Riege, 2003).

\subsection{External validity and transferability}

Transferability was obtained through the provision of "thick" descriptions of data (Bowen, 2005, p. 216). This will allow other researchers to transfer the findings of this study to new contexts in their studies by using it as a framework for reflection (Terre Blanche \& Durrheim, 1999). In other words, transferability should supply the tools or data for other researchers to determine if the results of this study are applicable within their context.

\subsection{Reliability and dependability}

Since reliability and dependability are concerned with the reproducibility of the findings, the researcher should ensure a clear and transparent process, which includes limitations of the study, as well as anticipated contributions (Crescentini \& Mainardi, 2009). Keeping audit trails is an activity that can enhance both the dependability and confirmability of a study. An audit trail can be established by "reviewing memos, logs, journals, field notes, computer files, and any other data pertaining to the research" (Lewis, 2009, p. 12).

\subsection{Objectivity and confirmability}

Chiovitti and Piran (2003, p. 432) called this criterion "auditability", which can be "demonstrated when another researcher is able to follow the audit or decision trail of all the decisions made by a researcher at every stage of the data analysis". The purpose of this is for examiners and other researchers to access if the interpretations and conclusions that are made in a particular study were "logical and unprejudiced" (Riege, 2003, p. 81).

\section{Conclusion}

In conclusion, this treatise shows that the research design, philosophy and approach have lent itself to a unique GT research study, which dealt with career transition. The specific information or uniqueness was highlighted by the researchers' own scientific beliefs, as well as their believes and preferences regarding the different GT schools of thought. In addition, this paper showed that although much planning was required to ensure a trustworthy research study, the steps that were outlined remained mere guidelines to follow. In other words, although the Strausarian school of thought provided step-by-step guidelines for coding, the GT process was still flexible enough to cater for individual needs 
and beliefs. The main point of this paper highlights that any GT approach can be applied, as long as it is properly defined, explained and aligned to the researcher's scientific beliefs.

\section{References}

Aldisert, L. (2002). Valuing people. United States of America: Dearborn Trade Publishing.

Allan, G. (2003). A critique of using grounded theory as a research method. Electronic Journal of Business Research Methods, 2(1), 110.

Atherton, A., \& Elsmore, P. (2007). Structuring qualitative enquiry in management and organization research. Qualitative Research in Organizations and Management: An International Journal, 2(1), 62-77.

Bailey, M. (2003). Uncertainty and Career Transition. Retrieved March 24, 2010, from Career-Tests-Guide: http://www.career-testsguide.com/career-transition.html

Bandow, D., Minsky, B., \& Voss, R. (2007). Reinventing the Future: Investigating Career Transitions from Industry to Academia. Journal of Human Resource Education, 1(1), 23-37.

Baruch, Y. (2004). Transforming careers: from linear to multidirectional career paths. Career Development International, 9(1), 58-73.

Baruch, Y., \& Quick, J. (2007). Understanding Second Careers: Lessons from a Study of U.S Navy Admirals. Human Resource Management, 46(4), 471-491.

Benecke, G., Schurink, W., \& Roodt, G. (2007). Towards a substantive theory of synergy. SA Journal of Human Resource Management, 5(2), 9-19.

Booth, W., Colomb, G., \& Williams, J. (1995). The Craft of research. Chicago: University of Chicago Press.

Bowen, G. (2005). Preparing a Qualitative Research-Based Dissertation: Lessons Learnt. The Qualitative Report, 10(2), 208-222.

Bridgstock, R. (2011). Skills for creative industries graduate success. Eduation + Training, 53(1), 9-26.

Bridgstock, R. (2011). Skills for creative industries graduate success. Education + Training, 53(1), 9-26.

Brousseau, K., Driver, M., Eneroth, K., \& Larsson, R. (1993). Career pandemonium: Realigning organizations and individuals. Academy of Management Executive, 10(4), 52-66.

Brousseau, K., Driver, M., Eneroth, K., \& Larsson, R. (1996). Career pandemonium: Realigning organizations and individuals. Academy of Management Executive, 10(4), 52-66.

Bryant, A., \& Charmaz, K. (2007). Introduction Grounded Theory Research: Methods and Practices. In A. Bryant, \& K. Charmaz, The SAGE Handbook of Grounded Theory (pp. 1-28). Los Angeles: SAGE Publications.

Burden, J., \& Roodt, G. (2007). Grounded Theory and its Application in a Recent Study on Organisational Redesign: Some Reflections and Guidelines. SA Journal of Human Resource Management, 5(3), 11-18.

Butcher, D., \& Harvey, P. (1998). Metqa-abilitly development: a new concept for career management. Career Development International, $3(2), 75-78$.

Carless, D., \& Douglas, K. (2009, Mar). "We haven't got a seat on the bus for you" or "al the seats are mine": narratives and career transition in professional golf. Qualitative Research in Sport and Exercise, 1(1), 51-66.

Carson, K., \& Carson, P. (1997). Career entrenchment: A quit march toward occupational death? Academy of Management Executive, $11(1), 62-75$.

Chari, S. (2008). Handling career role transitions with confidence. The International Journal of Clinical Leadership, 16, 109-114.

Charmaz. (2006). Constructing Grounded Theory, A Practical Guide Through Qualitatie Analysis. London: SAGE Publications.

Charmaz. (2006). Constructing Grounded Theory, A Practical Guide Through Qualitative Analysis. London: SAGE Publications.

Charmaz, K. (2006). Constructing Grounded Theory, A Practical Guide Through Qualitatie Analysis. London: SAGE Publications.

Chiovitti, R., \& Piran, N. (2003). Rigour and grounded theory research. Journal of Advanced Nursing, 44(4), 427-435.

Chudzikowski, K., Demel, B., Mayrhofer, W., Briscoe, J., Unite, J., Milikic, B., et al. (2009). Career transitions and their causes: A country-comparative perspective. Journal of Occupational Psychology, 82, 825-849.

Clarke, M. (2009). Plodders, pragmatsts, visionaries and opportunists: career patterns and employabilitliy. Career Development International, 14(1), 8-28.

Corbin, J., \& Strauss, A. (1990). Grounded Theory Research: Procedures, Canons, and Evaluative Criteria. Qualitative Sociology, 13(1), 3-21.

Corbin, J., \& Strauss, A. (1990). Grounded Theory Research: Procedures, Canons, and Evaluative Criteria. Qualitative Sociology, 13(1), 3-21.

Corbin, J., \& Strauss, A. (2008). Basics of Qualitative Research (3rd ed.). United States of America: Sage Publications.

Corbin, J., \& Strauss, A. (2008). Basics of Qualitative Research (3rd ed.). California: Sage Publications.

Corbin, J., \& Strauss, A. (2008). Basics of Qualitative Research. Techniques and Procedures for Dveloping Grounded Theory (3e ed.). Los Angeles: SAGE Publications.

Corbin, J., \& Strauss, A. (2008). Basics of Qualitative Research. Techniques and Procedures for Dveloping Grounded Theory (3rd ed.). Los Angeles: SAGE Publications.

Crescentini, A., \& Mainardi, G. (2009). Qualitative research articles: guidelines, sugestions and needs. Journal of Workplace Learning, 25(5), 431-439.

Crosson, F. (2005). Research Philosophy: towards and understanding. Nurse Researcher, 11(1), 46-55. 
De Briun, G., \& Buchner, M. (2010). Factor and item response theory analysis of the Protean and Boundaryless Career Attitude Scales. SA Journal of Industrial Psychology, 36(2).

De Vos, A., Dewettinck, K., \& Buyens, D. (2008). To move or not to move? The relationship between career management and preferred career moves. Employee Relations, 30(2), 156-175.

Denzin, N., \& Lincoln, Y. (2000). Handbook of Qualitative Research (2nd ed.). London: SAGE Publications.

Denzin, N., \& Lincoln, Y. (2005). The SAGE Handbook of Qualitative Research. Thousand Oaks, California: SAGE Publications Inc.

Denzin, N., \& Lincoln, Y. (2005). The SAGE Handbook of Qualitative Research. Thousand Oaks, California: SAGE Publications.

Dey, I. (1993). Qualitative Data Analysis. London: Routledge.

Dixon, P., Pickard, A., \& Robson, H. (2002). Developing a criteria-based quality framework for measuring value. Performance Measurement and Metrics, 3(1), 5-9.

Doer, D. (1995). Coping with the Emotions of Job Transition: A Model for Presentation to Clients. Journal of Career Development, 22(2), 101-107.

Donahue, R. (2006). Person-environment congruence in relation to career change and career persistence. Journal of Vocational Behaviour, 68, 504-515.

Dries, N., Pepermans, R., \& De Kerpel, E. (2008). Exploring four generations' beliefs about career. Journal of Managerial Psychology, 23(8), 907-928.

Duberley, J., Mallon, M., \& Cohen, L. (2006). Exploring career transitions: accounting for structure and agency. Personnel Review, 35(3), 281-296.

Ebaugh, H. (1988). Becoming and ex: The process of role exit. Chicago, IL: University of Chacago Press.

Ebberwein, C., Krieshok, T., Ulven, J., \& Prosser, E. (2004, Jun). Voices in Transition: Lessons on Career Adaptability. The Career Development Quarterly, 52(4), 292-308.

El-Sabaa, S. (2001). The skills and career path of an effective project manager. International Journal of Project Management, $19,1-7$.

Fitz-enz, J., \& Davison, B. (2001). How to measure human resource management (Third ed.). New York: McGraw-Hill.

Foot, D., \& Vene, R. (1990, Dec). Population, Pyramids and Promotional Prospects. Canadian Public Policy / Analyse de Politiques, 16(4), 387-398.

Ford, E. (2008, Feb 14). How to change career. Retrieved Oct 14, 2009, from Times Online: http://business.timesonline.co.uk /tol/business/career_and)jobs/graduate_management/...

Forrier, A., Sels, L., \& Stynen, D. (2009). Career mobility at the intersection between agend and structure: A conceptual model. Journal of Occupational and Organizational Psychology, 82, 739-759.

Frank, W. (1996). The 11 Steps in Career Transition. Retrieved OCt 14, 2009, from Career Lab: http://www.careerlab.com lart_11steps.htm

Fritz, R. (2010). Navigating Career Transitions. AMWA Journal, 25(2), 87-88.

Gerber, M., Wittekind, A., Grote, G., Conway, N., \& Guest, D. (2009). Generalizability of career orientations: A comparative study in Switzerland and Great Britain. Journal of Occupational and Organizational Psychology, 82, 779-801.

Giske, T., \& Arthinian, B. (2007). A Personal Experience of Working with Classical Grounded Theory: From Beginner to Experienced Grounded Theorist. International Journal of Qualitative Methods, 6(4), 67-80.

Glaser. (1978). Theoretical Sensitivity. Mill Valey: Sociology Press.

Glaser. (1978). Theoretical Sensitivity. Mill Valey: Sociology Press.

Glaser. (1992). Basics of grounded theory analysis: Emergence vs. forcing. Mill Valley, CA: Sociology Press.

Glaser. (1992). Basics of grounded theory analysis: Emergence vs. forcing. Mill Valley, CA: Sociology Press.

Glaser. (2002). Conceptualization: On Theory and Theorizing Using Grounded Theory. International Journal of Qualitative MEthods, $1(2), 1-31$.

Glaser. (2002). Conceptualization: On Theory and Theorizing Using Grounded Theory. International Journal of Qualitative MEthods, 1(2), 1-31.

Glaser, B. (1992). Basics of grounded theory analysis: Emergence vs. forcing. Mill Valley, CA: Sociology Press.

Glaser, B., \& Strauss, A. (1967). The Discovery of Grounded Theory. Chicago: Aldine.

Golafshani, N. (2003). Understanding Reliability and Validity in Qualitative Research. The Qualitative Report, 8(4), 597-607.

Goulding, C. (1999, June). Grounded Theory: some reflections on paradigm, procedures and misconceptions. University of Wolverhampton.

Goulding, C. (2002). Grounded Theory. A Practical Guide for Management, Business and Market Researchers. London: SAGE Publications Ltd.

Goulding, C. (2002). Grounded Theory. A Practical Guide for Management, Business and Market Researchers. London: SAGE Publications.

Greckhamer, T., \& Koro-Ljungberg, M. (2005). The erosion of a method: examples from grounded theory. 18(6), 729-750.

Greenhaus, J., \& Callanan, G. (1994). Career Management (Second ed.). Fort Worth Philadelphia: Harcourt BraceCollege Publishers.

Grinyer, A. (2002, Spring). The Anonymity of Research Participants: Assumptions, Ethics and Practicalities. (N. Gilbert, Ed.) Sociology at Surrey(36).

Grzeda, M. (1999). Re-conceptualizing career change: a career development perspective. Career Development International, 4(6), 305311.

Guba, E., \& Lincoln, Y. (1981). Effective evaluation: Improving the usefulness of evaluation results through responsive and naturalistic 
approaches. San Francisco, CA: Jossey-Bass.

Guidry, J. (2002). LibQual+ ${ }^{\mathrm{TM}}$ spring 2001 comments: a qualitative analysis using Atlas.ti. Performance Maangement and Metrics, 3(2), 100-107.

Gummesson, E. (2006). Qualitative research in management: addressing complexity, context and persona. Management Decision, 44(2), 167-179.

Hall, D. (1996). Protean Careers of the 21st Century. Academy of Management Executive, 10(4), 8-16.

Hall, D., \& Chandler, D. (2005). Psychological success: When the career is a a calling. Journal of Organizational Behavior, 26(2), 155176.

Handy, C. (1994). The Empty Raincoat: Making Sense of the Future. London: Hutchinson.

Handy, C. (1994). The Empty Raincoat: MAking Sense of the Future. London: Hutchinson.

Hanisch, K. (1999). Job loss and unemployment research from 1994 to 1998: a review and recommendations for research and intervention. Journal of Vocational Behaviour, 55, 188-220.

Hayes, N. (1997). Doing Qualitative Analysis in Psychology. Taylor and Francis, Inc.

Holton, J. (2007). The Coding Process and Its CHallenges. In A. Bryant, \& K. Charmaz, The SAGE Handbook of Grounded Theory (pp. 265-289). Los Angeles: SAGE Publications.

Ibarra, H. (2002, Dec). How to Stay Stuck in the Wrong Career. Harvard Business Review, 40-47.

Ibarra, H. (2004, 12 13). Career Transition and Change. Retrieved 12 18, 2012, from Insead: http://www.insead.edu/facultyresearch /research/doc.cfm?did=1477

Jackson, C. (1996). Managing and Developing a Boundaryless Career: Lessons from Dance and Drama. European Journal of Work and Organizational Psychology, 5(4), 617-628.

Kanchier, C., \& Unruh, W. (1989). Factors influencing career change. International Journal for the Advancement of Counseling, 12, 309321.

Kelly, A., Brannick, T., Hulpke, J., Levine, J., \& To, M. (2003). Linking organisational training and development practices with new forms of career structure: a cross-national exploration. Journal of European Industrial Training, 27(2/3/4), 160-168.

Kormanik, M. (2005). White Males in Transition: Describing the Experience of a Stalled Career. Dissertation.

Kraus, S. (2005). Research Paradigms and Meaning Making: A Primer. The Qualitative Report, 10(4), 758-770.

LaRossa, R. (2005, November). Grounded Theory MEthods and Qualitative Family Research. Journal of Marriage and Family, 67, $837-$ 857.

Leibowitz, A., \& Schlossberg, N. (1982, February). Critical Career Transitions: A Model for Designing Career Services. Training and Development Journal, pp. 12-19.

Levchuck, C. (2009). How to Chanage Careers Part 1: Is a Career Change Right for You? Retrieved Oct 16, 2009 , from Yahoo Hot Jobs: http://hotjobs.yahoo/careerchange/How_to_Change_Careers_Part_1_Is_a_Career...

Lewis, J. (2009). Redefining Qualitative Methods: Believability in the Fifth Moment. International Journal of Qualitative Methods, 8(2), 114.

Lichtenstein, B., \& Mendenhall, M. (2002). Non-linearity and response-ability: Emergent order in 21st-centurary careers. Human Relations, 55(1), 5-32.

Locke, K. (2001). Grounded Theory in Management Research. London: SAGE Publications.

London, M. (1983). Toward a theory of career motivation. Academy of Management Review, 8(4), 620-630.

Louis, M. (1980, Jul). Career Transitions: Varieties and Commonalities. The Academy of Management Review, 5(3), 329-340.

Louis, M. (1982). Managing Career Transition: A Missing Link in Career Development. Organizational Dynamics, 10(4), 68-77.

Lunsford, T., \& Lunsford, B. (1995). Research Forum - The Research Sample. Retrieved 02 15, 2012, from American Academy of Orthotists \& Prostetists: http://www.oandp.org/jpo/library/1995_03_105.asp

Mallon, M. (1999). Going "portfolio": making sense of changing careers. Career Development International, 4(7), 358-369.

Markov, N. (2011, Fall). Career Moves. Nafe Magazine, pp. 29-31.

Marks, A. (2010). The professional status of message therapists: experience, employability, and evolution. Journal of Human Resource Costing \& Accounting, 14(2), 129-150.

Martin, H., \& Lekan, D. (2008). Individual differences in outplacement success. Career Development International, 13(5), 425-439.

Mayrhofer, W., Meyer, M., Schiffinger, M., \& Schmidt, A. (2008). The influence of family responsibilities, career fields and gender on career success. Journal of Managerial Psychology, 23(3), 292-323.

Mays, N., \& Pope, C. (2000). Qualitative research in health care. Assessing quality in qualitatve research. BMJ, 320, 50-52.

McDonald, P., Brown, K., \& Bradley, L. (2005). Have traditional career paths given way to protean ones? Evidence from senior managers in the Australian public sector. Career Development International, 10(2), 109-129.

McGregor, D. (1960). The Human Side of Enterprise. New York: McGraw-Hill.

Mihail, D. (2008). Grauates' career orientations and strategies in corporate Greece. Personnel Review, 37(4), 393-411.

Mihal, W., Sorce, P., \& Comte, T. (1984, Jan). A Process Model of Individual Career Decision Making. The Academy of Management Review, 9(1), 95-103.

Mihal, W., Sorce, P., \& Comte, T. (1984). A Process Model of Individual Career Decision Making. The Academy of Management Review, 9(1), 95-103.

Mills, J., Bonner, A., \& Francis, K. (2006, April). The Development of Contructivist Grounded Theory. Retrieved December 19, 2011, from http://www.ualberta.ca/ iiqm/backissues/5_1/html/mills.htm 
Moen, P. (2005, Jun). Beyond the Career Mystique: "Time in," "Time Out," and "Second Acts". Sociological Forum, 20(2), $189-208$.

Morse, J., Barrett, M., Mayan, M., Olson, K., \& Spiers, J. (2002). Verification Strategies for Establishing Reliability and Validity in Qyalitative Research. Retrieved 12 18, 2012, from http://www.ualberta.ca/ iiqm/backissues/1_2Final/html/morse.html

Morse, J., Stern, P., Corbin, J., Bowers, B., Charmaz, K., \& Clarke, A. (2009). Developing Groundèd Theory. The Second Generation. Walnut Creek, CA: Left Coast Press Inc.

Mulligan, M. (2006). Moving Out \& Moving Up. United States of America: Liberty of Congress Caaloging in Publication Data.

Mulligan, M. (2006). Moving Out \& Moving Up. Bloomington: Liberty of Congress Caaloging in Publication Data.

Murtagh, N., Lopes, P., \& Lyons, E. (2007). Waht makes a career barrier a barrier? Industrial and Commerical Training, 39(6), $332-339$.

Myers, M. (2009). Qualitative Research in Business Management. London: SAGE Publications.

Nakkeeran, N., \& Zodpey, S. (2012). Qualitative Research in Applied Situations: Strategies to Ensure Rigor and Validity. Indian Journal of Public Health, 56(1), 4-11.

Pandit, N. (1996). The Creation of Theory: A Recent Application of the Grounded Theory Method. The Qualitative Report, 2(4).

Patton, M. (1980). Qualitatie evaluation methos. Beverly Hills: Sage.

Peel, S., \& Inkson, K. (2008). Contracting and careers: choosing between self and organizational employment. Career Development International, 9(6), 512-558.

Peterson, C. (2005). Get, Keep, Grow. In M. Losey, S. Meisinger, \& D. Ulrich, The Future of Human Resource Management (pp. 38-43). Alexandria, Virginia, USA: John Wiley\& Sons, Inc.

Pidgeon, N., \& Henwood, K. (1997). Using grounded theory in psychological research. In N. Hayes, Doing Qualitative Analysis in Psychology (pp. 245-273). Taylor \& Francis Inc.

Plimmer, G., \& Schmidt, A. (2007, Summer). Possible Selves and Career Transition: It's who you want to be, not what you want to do. New Directions for Adult Continuing Education, pp. 61-74.

Potter, W. (1996). An Analysis of Thinking and Research about Qualitative MEthods. New Jersey: Lawrence Erlbaum Associates Publishers.

Pringle, J., \& Dixon, K. (2003). Re-incarnating life in the careers of women. Career Development International, 291-300.

Reetley, A. (2008, Nov 12). A literature review on grounded theory. Retrieved Apr 12, 2011, from UJDigiSpace: http://ujdigispace.uj.ac.za:8080/dgspace/handle/102/1612

Reich, B., \& Kaarst-Brown, M. (1999). "Seeding the Line": Understanding the Transition form IT to Non-IT Careers. MIS Quarterly, 23(3), 337-364.

Rettie, R., Robinson, H., Radke, A., \& Ye, X. (2008). CAQDAS: a supplementary tool for qualitative market research. Qualitative Market Research: An International Journal, 11(4), 76-88.

Rhodes, S., \& Doering, M. (1983, Oct). An Integrated Model of Career Change. The Academy of Management Review, 8(4), 631-639.

Riege, A. (2003). Validity and reliability tests in case study research: a literature review with "hands-on" applications for each research phase. Qualitative Market Research: An International Journal, 6(2), 75-86.

Riegler, A. (2001). Towards a Radical Cpmstructivist Understanding of Science. Foundations of Science, 6, 1-30.

Robbins, S. (2001). Organizational Behavior. UpperSaddle River, New Jersey: Prentice Hall International, Inc.

Rolfe, G. (2006). Validuty, trustworthiness and rigour: quality and the idea of qualitative research. Journal of Advanced Nursing, 53(3), 3004-310.

Roncaglia, I. (2006, Nov). Retirement as a career transition in ballet dancers. International Journak if Educational and Vocational Guidance, 6, 181-193.

Sargent, L., \& Domberger, S. (2007). Exploring the development of a protean career orientation: values and image violation. Career Development International, 12(6), 545-564.

Saunders, M., Lewis, P., \& Thornhill, A. (2003). Research Methods for Business Students (3 ed.). England: Pearson Educational Limited.

Saunders, M., Lewis, P., \& Thornhill, A. (2003). Research Methods for Business Students (3 ed.). Harlow: Pearson Educational Limited.

Schein, E. (1984, Jan). Culture as an Environmental Cotext for Careers. Journal of Occupational Behaviour, 5(1), 71-81.

Schein, E. (1988). Organizational Psychology. Englewood Cliffs: Prentice-Hall Inc.

Schein, E. (1988). Organizational Psychology. Englewood Cliffs: Prentice-Hall.

Schein, E. (1996). Career anchors revisited: Implications for career development in the 21st century. Academy of Management Executive, 00(0), 80-86.

Schein, E. (1996). Career anchors revisited: Implications for career development in the 21st century. Academy of Management Executive, 80-86.

Scheurich, J. (1997). Research Methods in the postmodern. London: Falmer Press.

Scheurich, J. (1997). Research MEthods in the postmodern. London: Falmer Press.

Schlossberg, N. (1981). A model for analysing human adaptation to transition. The Counseling Psychologist, 9, 2-18.

Stern, P. (2007). On Solid Ground: Essential Properties for Growing Grounded Theory. In A. Bryant, \& K. Charmaz, The SAGE Handbook of Grounded Theory (pp. 114-126). Los Angeles: SAGE Publications.

Strauss, A. (1987). Qualitative Analysis for Social Scientist. New York: Cambridge University Press.

Suddaby, R. (2006). From the Editors: What Grounded Theory is Not. Academy of Management Journal, 49(4), 633-642.

Sullivan, S., Carden, W., \& Martin, D. (1998). Careers in the next millennium: Directions for future research. Human Resource Management Review, 8(2), 165-185. 
Suutari, V., \& Taka, M. (2004). Career anchors of managers with global careeers. Journal of Management Development, 23(9), 833-847.

Tan, J. (2010). Grounded theory in practice: issues and discussion for new qualitative researchers. Journal of Documentation, 66(1), 93112.

Teixeira, M., \& Gomes, W. (2000). Autonomous Career Change Among Professionals: An Emperical Phenomenological Study. Journal of Phenomenological Psychology, 31(1), 78-96.

Terre Blanche, M., \& Durrheim, K. (1999). Research in Practice. Applied Methods for the Social Science. Cape Town: University of Cape Town Press (Pty) Ltd.

Terre Blanche, M., \& Durrheim, K. (1999). Research in Practice. Applied Methods for the Social Science. Cape Town: University of Cape Town Press.

TerreBlanche, M., \& Durrheim, K. (1999). Research in Practice. Applied methods for the social sciences. Cape Town: University of Cape Town Press.

Thomas, G., \& James, D. (2006). Reinventing grounded theory: some questions abouth theory, ground and discovery. British Educational Research journal, 32(6), 767-795.

Thomas, G., \& James, D. (2006). Reinventing grounded theory: some questions abouth theory, ground and discovery. British Educational Research Journal, 32(6), 767-795.

Thorne, S. (2000). Data analysis in qualitative research. Evidence-Based Nursing, 3, 68-70.

Trochim, W. (2006). Deduction \& Induction. Deduction and Inductive Thinking. Retrieved Nov 2, 2009, from http://www.socialresearchmethods.net/kb/dedind.php

Tsui, A., \& Wu, J. (2005). The new employment relationship versus the mutual investment approach: Implications for human resource management. In M. Losey, S. Meisinger, \& D. Ulrich, The Future of Human Resource Management (pp. 44-54). Alexandria, Virginia, USA: John Wiley\& ons, Inc.

Tsui, A., \& Wu, J. (2005). The new employment relationship versus the mutual investment approach: Implications for human resource management. In M. Losey, S. Meisinger, \& D. Ulrich, The Future of Human Resource Management (pp. 44-54). Alexandria, Virginia: John Wiley \& Sons.

Van Manen, M. (2006). Writing qualitatively, or the demands of writing. Qualitative Health Research, 16(5), 713-722.

Watson, C. (2005). Living the Life of the Social Inquirer: Beginning Educational Research. Forum Qualittive Soziaforschung / Forum: Qualitative Social Research, 6(2), 67 paragraphs.

Weber, S., \& White, M. (2008, July 21). Career Change Statistics. Retrieved Oct 14, 2009, from lovetoknow: http://jobs lovetoknow.com/Career_Change Statistics

Wexley, K., \& Latham, G. (1991). Developing and Training Human Resources in Organizations (Second ed.). New York: HarperCollins Publishers Inc.

Wexley, K., \& Latham, G. (1991). Developing and Training Human Resources in Organizations (Second ed.). New York: HarperCollins Publishers.

Whittemore, R., Chase, S., \& Mandle, C. (2001). Validity in Qualitative Research. Qualitative Health Research, 11(4), $522-537$.

Wilig, C. (2001). Introducing Qualitative Research in Psychology. Buckingham - \{hiladelphia: Open University Press.

Wilig, C. (2001). Introducing Qualitative Research in Psychology. Buckingham - Philadelphia: Open University Press.

Willig, C. (2001). Introducting Qualitative Research in Psychology. Buckinham - Philadelphia: Open University Press.

Willig, C. (2008). Introducing Qualitative Research in Psychology (2nd Edition ed.). New York: Open University Press McGraw-Hill Education.

Willis, J. (2007). Foundations of Qualitative Research - Interpretive and Critical Approaches. Thousand Oaks, California: SAGE Publications.

Wise, A., \& Millward, L. (2005). The experiences of voluntary career change in 30-somethings and implications for guidance. Career Development International, 10(5), 400-417.

Woodd, M. (2000). The move towards a different career pattern: are women better prepared than men for a modern career? Career Development International, 5(2), 99-105.

Yin, R. (1989). Case Study research: Design and Mehtods. London: SAGE Publications.

Zheng, Y., \& Kleiner, B. (2001). Developments concerning career development and transition. Management Reserach News, 24(3/4), 339. 